\title{
The synergy of marine fishing and the eco-tourism sector as the solution in resolving poverty of fishermen
}

\author{
Sinergi sektor perikanan tangkap dan ekowisata bahari untuk mengatasi kemiskinan \\ nelayan
}

\author{
Sunarlan ${ }^{1} \&$ Kusnadi $^{2}$
}

${ }^{1}$ Department of History, Faculty of Humanities, Universitas Jember

${ }^{2}$ Department of Indonesian Language and Literature, Faculty of Humanities, Universitas Jember Address: Jalan Kalimantan No. 37, Kampus Tegalboto, Sumbersari, Jember, East Java 68121

E-mail: sunarlan2010@gmail.com \& welfarestate@yahoo.co.id

\begin{abstract}
The socio-economic condition of the traditional fishermen in Blimbingsari Village is considered to be less than the optimum. This problem has happened due to the diminishing revenue from fishing activities. The opportunity to work in the off-fishing sectors available are also limited, thus this creates a problem for the fishermen when it comes to earning an additional income. The objective of this article is to explore the alternative economic resources' potential, with the aim of increasing the fishermen's revenue, to overcome poverty, and to improve their welfare. This study used a qualitative method to analyse the data. The results of the study reveal that the diminishing revenue of the fishermen is caused by the scarcity of the fishery resources, the unstable weather conditions that affect the ability to sail, and the limited seafaring coverage. On the other hand, the marine eco-tourism sector may have the opportunity to assist in the improvement of the business diversification of fishing. Although the marine eco-tourism sector is running at a limited capacity, this sector is able to accommodate the development of tourism services. The fishermen's family members are able to be involved in their business activities. For instance, by becoming a helper in the fish stall business or even having the chance to establish their own business. The need for a fish supply for the fish stall business can be obtained from the local fishermen. Therefore, a mutual synergy between the eco-tourism and fishing sectors can be created by involving village-owned business, particularly when it comes to organising the local economic potential. This synergy can provide the chance to develop economic opportunities at a wider range. The rearrangement of the coastal area is also necessary to provide an opportunity for the local people to participate in coastal-based economic activities.
\end{abstract}

Keywords: fishermen, poverty, marine eco-tourism, inter-sectoral synergy

\begin{abstract}
Abstrak
Kondisi sosial ekonomi nelayan tradisional di Desa Blimbingsari masih terbatas. Hal ini disebabkan oleh menurunnya tingkat pendapatan dari kegiatan melaut. Peluang-peluang kerja di luar sektor penangkapan (off fishing) juga terbatas sehingga menyulitkan nelayan memperoleh pendapatan tambahan. Kegiatan penelitian ini dilaksanakan untuk menggali potensi sumber-sumber ekonomi alternatif dengan tujuan meningkatkan penghasilan nelayan, mengatasi kemiskinan, dan meningkatkan kesejahteraannya. Penelitian ini menggunakan pendekatan kualitatif. Hasil penelitian ini menunjukkan bahwa penurunan pendapatan nelayan disebabkan oleh kelangkaan sumber daya perikanan, hambatan melaut karena kondisi cuaca yang tidak stabil, dan keterbatasan daya jangkau melaut. Pada sisi lain, terdapat sektor ekowisata bahari yang berpeluang dikembangkan untuk mendukung diversifikasi usaha nelayan. Meskipun masih terbatas, sektor ekowisata bahari dapat menampung aktivitas nelayan mengembangkan jasa-jasa wisata dan isteri-isteri mereka terlibat dalam penyediaan jasa tenaga usaha warung ikan bakar atau membuka usaha mandiri. Sebagian kebutuhan konsumsi ikan di warung-warung tersebut dipasok oleh nelayan lokal. Untuk menyinergikan antara sektor penangkapan dan ekowisata bahari, serta mengembangkan peluang-peluang ekonomi yang lebih luas, diperlukan keterlibatan BUMDes dalam mengorganisasikan potensi ekonomi lokal. Selain itu, diperlukan penataan ulang kawasan pesisir setempat, sehingga memberi peluang yang terbuka bagi masyarakat lokal untuk berpartisipasi dalam kegiatan perekonomian pesisir.
\end{abstract}

Kata kunci: nelayan; kemiskinan; ekowisata bahari; sinergi antarsektor 


\section{Introduction}

After nearly half a century since the modernisation of fisheries was carried out in the early 1970s, not all fishing villages have progressed in relation to their economic development and social welfare. The results of the study conducted in Pesisir Village in the Besuki Sub-district, Situbondo District, has confirmed the truth. Since 1996-2016, the social welfare conditions of the fishing community in Pesisir Village have not changed much, specifically that of traditional fishermen and labourers. They continue to live with various socio-economic difficulties (Kusnadi 1998, Kusnadi \& Sumarijono 2016). The implication of these limitations makes it difficult for fishermen to access education, health, and the right to better welfare.

The fishermen's villages that rely solely on the fishery sector as a source of income, such as the Pesisir Villages, have not had much progress in relation to improving their social welfare. Their economic productivity is affected by the declining amount of potential fishery resources that is caused by overfishing, a lack of weather forecast information, and the lack of fish finding technology. Since 2015, a similar problem had occurred in Blimbingsari Village. This village's diminishing revenue even put them in a state of poverty. The flagging economic development of Blimbingsari Village is a proven example of how one economic sector can affect fundamental aspects of the localised society. Therefore, the villagers need alternative sectors that can be explored to support the fishing sector and to ensure that the village's economic development is sustainable.

This study was conducted for several reasons. First, in general, the fishing villagers face a poverty situation which complicates the attainment of better social welfare. Based on the data from the Central Bureau of Statistics (2014), the number of households that work as fishermen (capture, public waters, and cultivation) reached 964,231 or $1.5 \%$ of the total national households. The overall number of indigent fishermen households was $72.21 \%$, while the income per capita of the capture fisherman households was Rp737.030. The capture fishermen's household income per year was Rp3.030.200 (Muhammad 2016). This data indicates that the socio-economic capacity of the fishermen's households is relatively limited. In the case of Blimbingsari Village, since 2015 up to now 2017, the local fishermen are still facing difficulties when it comes to capturing fish due to the scarcity of fishery potential in the local waters. In consequence, the income and welfare levels are directly affected.

Second, up to August 2017, eco-tourism economic activities and capture fisheries are still running separately. There is no blueprint about the synergy and integration of the fishing, eco-tourism, and trade sectors. The social (economy) institution that manages the integration of coastal economic sectors has also not yet been built. Such conditions will complicate the growth of coastal economic development.

Third, the socio-economic changes are expected to take place rapidly in Blimbingsari Village, due to its strategic location. Blimbingsari Village is located in the north of Banyuwangi Airport complex. This area is anticipated to develop within the next 5-10 years. Consequently, a new economic area will merge Rogojampi City and Blimbingsari Village. Within this situation, the villagers of Blimbingsari are also expected to be ready and to be able to follow the acceleration of the area's development. There have been some cases that show that such areas have experienced economic development as a result of urban expansion (Yunus 2008).

Considering the reasons above, this study was conducted in order to answer the question of how to synergise the sectors of marine fishing and eco-tourism to support the development of Blimbingsari Village's local economy. The same kind of synergy has been applied in Izola, Southern Europe (Rogelja 2002:85-102). The purpose of synergising both marine sectors is to generate economic opportunity, to increase the fishermen's revenue, and to allow them to overcome their poverty. Furthermore, the objectives of the research are as follows: (1) to acquire the description of the fishermen's socio-economic condition, (2) to obtain the description of marine eco-tourism activity 
dynamics, and (3) to attain a description of marine fishing and eco-tourism sector synergy strategy, which is orientated to expand working opportunities and to overcome the poverty of fishermen in coastal areas.

\section{Research Method}

This study was conducted in Blimbingsari Village, a fishermen's village, located in Pesisir Timur, Banyuwangi District, and used a qualitative research method (Afrizal 2015). The informants of this research study were obtained using the snowball technique, consisting of key informants and supporting informants. The number of the informants interviewed was adjusted in relation to the adequate amount of data that needed to be analysed.

The research data consisted of primary and secondary data. The primary data was obtained through a series of in-depth interviews with the informants and by observing the villagers' activities. The data was validated using the triangulation method, which uses multiple data sources to produce an understanding of the problem. The secondary data was collected in the form of statistical data, official documents, archive material, and relevant literature. The entirety of the data was collected, categorised and selected simultaneously as the materials of the data analysis.

The data analysis and data interpretation was carried out from the beginning of the field observations through to the time of the conclusion being made. Due to the in-depth analysis and the circumstances where a social phenomenon cannot stand on its own but is following the law of dialectics and causation, the analytical process needs to be guided by the principle of causality (Little 1991:138). The construction of a comprehensive interpretation is the end result of the study.

\section{Results and Discussion}

\section{The economic limitations of the fishermen's community}

The problem of the economic limitations or poverty in the fishermen's community is a serious issue that still occurs today, and has not been addressed properly. The fisheries' modernisation in the 1970s is often seen of as the cause of poverty and social inequality among the fishing communities (Mubyarto et al. 1984, Suyanto 1993). In subsequent developments, the factors that cause the poverty in the fishermen have become more complicated. For instance, the destruction of marine coastal ecosystems and the fish catching process, which damages the environment due to the use of fish bombs and potassium. The destruction of the ecosystems has reduced the income level of the fishermen (Ismail 2003). In addition, climate change, the lack of high-quality technology, and unequal access to the market are worsens the situation and leads to the fishermen's poverty (Muqtafa \& Nadila 2011, Perry 2010, Imron 2003). Other factors which are also involved are the quality of the fishermen's human resources, the exploitative profit-sharing system, and the attachment of debt with the intermediary traders (Kusnadi 2006).

From 2015 to 2017, the traditional fishermen in Blimbingsari have met with difficulties in relation to capturing fish. Such difficulties have occurred throughout the year, including during the fishing seasons (Western and Eastern seasons). When the fishing seasons were still running regularly years ago, the fishermen only had a difficult time fishing between May and September, in the Eastern season. On the contrary, the Western season that happens between September and April was the best time for them to go fishing. Moreover, the fishermen are often facing obstacles when sailing to the sea. For example, sudden big waves and gales. According to the fishermen, the sea's climatic conditions have lost its regularity and this makes it difficult for them to anticipate it.

When it is not the fishing season, the fishermen will go fishing in North Bali's seawaters, particularly in Singaraja. In South Bali's seawaters, the fishermen choose to fish in Pangambengan, Kedonganan, Jimbaran, and Sembulungan (Muncar). In order to capture fish in that area, the fishermen incur greater operational costs due to the distance between their village and the fishing ground. In addition, 
the income is no longer necessarily larger than the operational costs. This speculative condition makes the fishermen need to take more considerations into account before sailing. Therefore, there are not many fishermen who choose to sail every day.

The condition of the fishery resource potential has begun to decline since 2009. During this time, the fishermen who lived in Krajan Sub-village started to leave the sea and looked for alternative opportunities to work on the land. Similarly, from July to August 2017, the fishermen who did not go to sea looked for other jobs. For example, by becoming builders and construction workers on the construction site of Blimbingsari Airport, or elsewhere. They also became farm workers or fishpond workers. Most of the others do not work, therefore to meet the daily needs of life, the wives of the fishermen must enter into debt when helped by their relatives and neighbours, or otherwise sell their valuable possessions.

In the activities related to the sea, the income levels obtained cannot be ascertained, as reported by a capture fisherman. For instance, on one day in August 2017, Harori went to sea and earned an income of Rp30.000. The cost of fishing consisted of two litres of gasoline - Rp20.000 and cigarettes - Rp5.000, so the total was Rp25.000. The income left over was Rp5.000. The day before, he had not earned money. Because of the small income he was getting, he stopped fishing for a while and worked as a bricklayer on the Blimbingsari Airport construction project. The daily wage he earned was Rp80.000 per day and this was cumulatively given every weekend. As a construction worker, his wage was Rp70.000 per day. Most of the Blimbingsari fishermen enter into this condition without having the ability to resolve the economic problems of the household thoroughly.

The small amount of income makes it hard for the fishermen to meet their daily needs. The average need for a small family of 4 or 5 people on a daily basis is Rp40.000 to Rp50.000. According to Widodo (2012:71-72), there are several indicators for measuring the poverty of fishermen. First, there is the low income level and the uncertainty of the amount that they earn. Second, is the limited amount of nutritious food that they are able to buy and eat. Third, is a house that is less than decent to live in and only has limited furnishings. Fourth, is the condition where the fishermen do not have any production assets. Fifth, is the lack of vehicle ownership for transportation. On average, the fishermen in Blimbingsari Village already have decent houses. However, this cannot ensure their economic capability. The facts above show that fishing as the main source of income for the villagers is no longer reliable. The climate change and the diminishing potential of fishery resources in a water-based region is a sign of a different natural condition compared to several years ago (Suyanto 2008:79).

The state of poverty seriously impacts on the future of the fishermen and the existence of the coastal region as a place to run economic activities. Nevertheless, the fishermen's ability to withstand various socio-economic pressures is a valuable aspect that supports their condition. In addition to this, there are local institutions that can help to overcome the poverty problem, while other institutions preserve poverty. Thus, the institutions that bring in a positive impact need to be strengthened to help to overcome the socio-economic difficulties (Humaedi 2011:83-110). Moreover, the local initiatives that aim to strengthen the resilience of fishermen facing poverty will also need to be well managed.

In addition to the socio-economic problems in place, the fishermen also concern about the sea abrasion that can erode the coastal areas. Since the 1970s, the Blimbingsari coastline has retreated by about 2.5 kilometres. The fishermen expect the district government to construct a breakwater in the coastal area to hold off the sea abrasion. If this problem is not addressed immediately, the remaining coastline may completely be destroyed by sea abrasion and endanger the fishermen's households in Pacemengan sub-village. This will cause new social problems.

\section{The dynamics of marine eco-tourism}

Marine eco-tourism is the natural tourism that relies on the beauty of the coast and sea, which is community-based and involves welfare enhancement. Marine eco-tourism is also educative tourism, in that it is oriented around the sustainability of natural resources (Tuwo 2011:28-29). There are four 
dimensions of interest that support the activities of marine eco-tourism, namely the sustainability of natural resources, economic progress, community welfare, and educational interests in order to develop the supporting science. These dimensions of interest are the pillars of sustainability of marine eco-tourism activities.

In some coastal villages or fishing villages, people are beginning to develop marine eco-tourism activities that integrated into fishing activities. The objective of this integration is to improve the dynamics of the local economy and to increase the fishermen's revenue and social welfare. The villagers have become economic players by engaging in the development of marine eco-tourism. It also raises people's awareness of the preservation of nature. Eco-tourism management can be seen in Les Village, Tejakula Sub-district, Buleleng District, North Bali (Kartodiharjo \& Jhamtani 2006:246255) and in Delegan Village, Gresik District (Kusnadi 2016).

In the last few years, experts have paid serious attention to the role of the tourism sector in resolving the poverty problem. Tingsabadh's research (2005:61-67) has shown that tourism development in Thailand has contributed to the government's efforts in resolving poverty, since tourism has created extensive job opportunities for its people, including those with a low level of education. Cruz's research (2005:68-81) in the Philippines also showed a similar result. In order to make use of tourism to solve the problem of poverty, tourism objectives should be directed to increase the number of tourists and the local income. In doing so, the Government Tourism Office works with local residents to manage the natural tourism potential. The authorities may conduct in-depth training to support tourism activities for the local residents. For example, hotel management expertise training, tour guides training, travel agent training, butterfly farming training, and also training to enhance the quality of bamboo handicraft products. Cooperative institutions also need to be established to assist in the continuity of the community-based tourism activities.

The community-based tourism management model that the WTO sees as a sustainable tourism activity is Community-Based Eco-tourism Management in Taman Nasional Gunung Halimun, West Java (Hartono 2005:82-91). Economic tourism activities are not only limited to the field of ecotourism, but they are also focused on the chance to look for alternative business opportunities for local communities without destroying the forests. In addition to that, the management also focuses on building partnerships with various agencies and each business partner must contribute to the upgrading of the community-based eco-tourism activities. Furthermore, when doing eco-tourism activities, the government must not deprive the local communities of their source of life by using "nature conservation" as the reason, as in Taman Wisata Alam, Ruteng, West Flores. The communities are relying on the forest resources around them to live (Erb 2001:72-88).

There was a research study conducted by Cole (1998:37-46) that tried to understand the application of two concepts in sustainable tourism development, namely the participation of local communities and equitable income distribution in Ngada, Flores. In practice, these two concepts are not easily manifested. According to the local residents, tourism activities are viewed positively, since these activities able to maintain and reinforce traditional values. The positive side has been proven by the increasing number of traditional houses, the reparation of Bhaga and Ngadu, and the re-implementation of customary social stratification systems. According to Cole, the local customs that tend to be culturally hierarchical can be re-utilised to support tourism activities, to prevent an income gap among the local communities. In doing so, we also need a common understanding to create a conducive situation that supports the equitable distribution of income. Thus, a tradition must be understood as a social construct that can be created and recreated by adjusting to the time (Adams 1997:309-320).

The marine tourism sector is very relevant to overcoming the fishermen's poverty problem (Damanik 2005:27). To support this notion, one of the principles that must be adhered to is developing a marine eco-tourism that is oriented to the fishermen's main activities. Through fishing, the fishermen's communities have a wider opportunity to be engaged in marine tourism. For instance, fishermen have opened up a sea tour where tourists can enjoy the fishermen's performance of fish capturing at sea. This idea of tourism service can help the fishermen to earn a better income. 
Besides the marine eco-tourism services which are provided by the fishermen, the fishermen's family members can also take part in eco-tourism by working at the grilled seafood stalls on the seaside of Bimbingsari Beach. There are 16 stalls lined up from North to South of Blimbingsari Beach. These stalls are built on the land where the land's right is divided between the village government and the association of local fishermen. The fishermen's association has the right to control eight stalls in the south, while the rest of the stalls are controlled by the village government. Therefore, the stall owner has to rent the land to the village government for Rp1.500.000 per year, or to the fishermen's association for Rp1.000.000 per year due to its smaller size.

The seafood stalls are open from $07.00 \mathrm{am}$ to $21.00 \mathrm{pm}$. These stalls sell various kind of fish, such as kerapu, potihan, kakap hitam, kakap putih, baronang, and bawal, with a minimum size of 3.3 ounces for each fish. Consumers prefer to buy various types of fish in one kilogram portions since they come in groups. For one kilogram of fish, the price range starts from Rp70.000 to Rp80.000. While on holiday or in a crowded state, the owner of the stall fixes the price to from Rp80.000 to Rp90.000 per kilogram.

The visitors to Blimbingsari Beach usually come from the small towns or villages in the Banyuwangi, Situbondo, Jember, Malang, and Surabaya Districts. The peak season for the Blimbingsari Beach to be visited in is Idul Fitri. Visitors come in small groups of around 15 to 20 people. In the peak season, the seafood stalls can sell more than 100 kilograms of fish per day, while on the regular days, they only sell around 15 kilograms. During the peak season, some stall owners have already stocked up to one ton of fish. In addition to this, the stall owners also increase the number of stalls' servants up to 15 to 20 people, while on the regular days, they only have three to five servants. The servants get paid Rp60.000 to Rp80.000 per day, while the important helpers get paid Rp100.000 per day. They work from $07.00 \mathrm{am}$ to $21.00 \mathrm{pm}$. Generally, the servants are the fishermen's family member or relatives, or close neighbours of the stall owner. Sometimes, other fishermen also help at the seafood stalls.

For the fishermen, the economic opportunities created by marine eco-tourism activities really helps their economic situation. As explained before, the wives and relatives of the fishermen can work as servants on the seafood stalls, although the bigger opportunities depend on the holiday season. The existence of these stalls also creates the opportunity for local fish traders (pangamba') to be the fish supplier. On the other hand, the involvement of the fishermen and their families in marine ecotourism activities is still limited and unstable. Nevertheless, this involvement indicates the existence of the synergy between marine sectors in the local economy dynamic of Blimbingsari Village.

\section{The cross-sector synergies}

The fishing and marine eco-tourism sectors are two sectors of the local economy in Blimbingsari Village that have the potential to be developed in synergy and integration. This synergy and integration has been seen in several coastal villages. However, each of these two sectors still has weaknesses and need serious improvement, so then the synergy will be able to drive forward the sustainable coastal economy activities, create new business opportunities, and provide economic benefits and prosperity to all of the villagers.

As mentioned in this study, there are several problems that have turned out to be the weaknesses of the fishing sector between 2015 to 2017. The first is the declining amount of captured fish due to the scarcity of the fishery resources. Second, is the lack of information from related institutions. Third, is the lack of technology in place to detect the existence of fishery resources. Fourth, is the operational costs, which tend to higher than the fishermen's income.

There are several efforts to be undertaken in order to overcome the weaknesses of the fishing sector. First, the fishermen need to get information about the weather or climatic conditions, and the exact place where the fishery resources are from the related institutions. Second, is for there to be encouragement for them to sail and to help them in capturing fish. Third, is to encourage the villagers to do coastal conservation by planting mangroves and establishing marine protected zones. Fourth, is 
to build the breakwater building in order to prevent sea abrasion. By doing so, these steps can restore the local fishery potentials near the coastal area in question, ease the fishermen's burden by saving on their operational costs, and saving the fishing village from abrasion.

In addition to the weaknesses in the fishery sector, there are also weaknesses in the marine ecotourism sector. These are limited coastal areas that can be used as the focus of more eco-tourism activities, limited supporting public facilities, and a limited number of human resources, who in turn can participate in eco-tourism. The later problems arise because of the limited coastal area that affects the opportunities for the villagers to open up a new business. In 2017, the existing seafood stalls have been surrounded by private entrepreneurs' fish ponds, while the southern part of the stalls have been used as a small dock for the fishermen's boats. Thus, the existing coastal area is no longer able to accommodate new economic activities.

To solve the limited space problem in the coastal area, we must rearrange and expand the space. The rearrangement must be accompanied by an integrated area development conception. In doing so, the local economic sectors will be able to develop synergistically and sustainably. Moreover, the allocation of the coastal area for public facilities must be clarified to make the rearrangement effective. The coastal area needs to be divided up based on its function. For instance, for the public spaces, business areas, community-based businesses, restaurants, grilled fish stalls, markets, terminals, community-based homestay, parks, and other public facilities. In short, comprehensive infrastructure development is believed to be able to manifest socio-economic progress for the local people.

In Blimbingsari Beach, marine eco-tourism naturally has created a cross-sector synergy between the fishing sector and marine eco-tourism sector. This synergy has been shown to have a positive impact, therefore the synergy needs more support from the village institution to assist in managing eco-tourism. The central or regional government also has shown its support for "village autonomy" by increasing the allocation value of village funding from year to year. This funding can be managed by Badan Usaha Milik Desa (BUMDes), which is competent in managing the village's economic potential. The rationale behind the participation of BUMDes is (1) that BUMDes is capable of managing the economic potential of the village in accordance with the law and (2) the land asset which is used for the establishment of marine eco-tourism buildings or facilities belongs to the village government.

BUMDes has the potential to make marine eco-tourism a business unit of the village that is involved in the local economic development in coastal areas. The general strategy of local economic development is that it aims to create (a) economic growth and employment; (b) a decrease in the number of poor and unemployed people; and (c) the realisation of a sustainable livelihood. Therefore, active support and integrated participation among the development actors for instance, the local government, private sector, and other development actors, both locally and regionally is needed. Local economic development is a cross-sectoral development concept as part of the conception of integrated regional development (Dendi et al. 2004:14-15).

In addition to the matters explained above, improving the quality of the human resources of the tourism actors is also needed to support the management of the marine eco-tourism potential effectively and professionally. This effort can be done by way of education and training activities through a partnership with the stakeholders of BUMDes. Training activities will not only transform the knowledge that is needed by the community, but also help to develop the technical skills needed to support the sustainable management of marine eco-tourism. Thus, the local residents have the ability and creative skills to develop the tourism services and will be able to present quality tourism products so then it can provide satisfaction to the tourists.

An actual example of BUMDes' involvement in community-based economic development and potential local resources can be seen in Ponggok Village, in the Klaten District. The village has considerable amounts of water potential. This potential was turned into water tourism, as they also use the water potential to supply clean water to the surrounding villages. The quality of the potential 
human resources was enhanced through skills training and the internalisation of tourism knowledge with various partners. They also used Internet-based information technology to promote and support the marketing of the village's tourism potential.

The cross-sector synergy that has manifested in Blimbingsari Village contributes to creating a self-reliant economy, welfare, and a sustainable livelihood for the fishermen. The conception of development based on local self-reliance recommends utilising the availability of natural resources and its characteristics (Amien 2005:171). In consequence of the developments that have been undertaken, there is new job diversification and employment opportunities in the off-fishing sector that helps the villagers to earn a better income and to live a more prosperous life. The improvement of life quality will help the villagers to gain socio-economic resilience when facing the accelerated economic development of their region. It also becomes a way to solve the poverty problem of the fishing communities. Therefore, the presence of the government as a part of its constitutional responsibilities is urgently needed to support and strengthen the economic progress of the fishing villages.

\section{Conclusion}

The traditional fishermen in Blimbingsari Village are one of the fishing communities with limited socio-economic welfare. The efforts to solely depend on fishing to support their lives and to improve their welfare can no longer be relied on continuously. This is due to the condition of the potential fishery resources in the Bali Strait, which has begun to decrease drastically since 2015. On the other hand, new economic opportunities in the off-fishing sector are very limited, so it cannot be expected to help the fishermen's households in overcoming the poverty problem.

Nevertheless, the marine eco-tourism sector in Blimbingsari Village has the great opportunity to develop and synergise with the fishing sector to create new sources of income for the fishing communities. Despite the positive value of the synergy, each sector still needs revamping. The marine eco-tourism sector requires the rearrangement of the local marine eco-tourism, the provision of public facilities, and the improvement of the human resource quality in eco-tourism. Meanwhile, the fishing sector requires the provision of climate information, potential fish resource position detectors and help in relation to fish nesting (rumpon), coastal and marine ecosystem conservation, and the breakwater construction to prevent the coastal abrasion.

Eco-tourism activities at Blimbingsari Beach have created a good opportunity for the fishermen and their families to participate in it. Nevertheless, the number of the villagers involved in 2017 is still limited. In fact, the fishermen want for more opportunities to actively engage with in relation to economic activities, primarily by opening up a new business as a part of job diversification. However, this is not easy to do given the limited space problem of the coastal area. Therefore, various improvements in the context of the marine cross-sector synergy are needed to contribute to opening up more job opportunities, increasing the villagers' income, and overcoming poverty. Moreover, the existence of Blimbingsari BUMDes and its authority has enhanced the management of the village's potential economy in a sustainable way.

To overcome the various problems that arise, the fishing villages still require support from the regional government, business partners, local communities, and other stakeholders. The development of the coastal economy, based on synergy and integration, requires the support of large resource potential. This integrated development strategy is expected to increase the income and welfare of the coastal communities in general, to overcome the poverty experienced by the fishermen, to maintain the livelihood of the community, and to maintain the stability of natural resource utilisation optimally and in a sustainable manner. Furthermore, it is a fundamental responsibility of the government and state to pay attention to the people's right to have a proper and prosperous life. The presence of the government's participation strengthens the villagers that have been capable of facing socio-economic changes triggered by the acceleration of regional development. 


\section{References}

Afrizal (2015) Metode Penelitian Kualitatif. Jakarta: Rajawali Pers.

Adams KM (1997) Etnic tourism and the renegotiation of tradition in Tana Toraja, Sulawesi, Indonesia. Ethnology, 36 (4):309-320.

Amien AM (2005) Kemandirian Lokal: Konsepsi Pembangunan, Organisasi, dan Pendidikan dari Perspektif Sains Baru. Jakarta: Gramedia.

Cole S (1998) Tradition and tourism, dilemmas in sustainable tourism development: A case study from the Ngada Region of Flores, Indonesia. Antropologi Indonesia, 22 (56):37-46.

Damanik J (2005) Penanggulangan Kemiskinan Melalui Pariwisata: Sari Konsep Menuju Implementasi. In: J Damanik, HA Kusworo, \& DT Raharjana (eds). Penanggulangan Kemiskinan melalui Pariwisata. Yogyakarta: Pusat Studi Pariwisata, Universitas Gadjah Mada, 17-33.

Dendi A, HeileHJ, Mahman, Hilaliyah R, \& Haryono RS (2004) Menanggulangi Kemiskinan Melalui Pengembangan Ekonomi Lokal: Beberapa Pelajaran dari Nusa Tenggara Barat. Jakarta: Laporan Penelitian, Direktorat Jenderal Bina Pembangunan Daerah, Departemen Dalam Negeri.

Erb M (2001) Eco-tourism and environmental conservation in Western Flores: Who Benefits?. Antropologi Indonesia, 24 (66):72-88.

Hartono T (2005) Pengalaman Kemitraan, Pengelolaan, dan Pemasaran Ekowisata Berbasis Masyarakat Lokal: Kasus Taman Nasional Gunung Halimun Salak, Jawa Barat. In: J Damanik, HA Kusworo, \& DT Raharjana (eds). Penanggulangan Kemiskinan Melalui Pariwisata. Yogyakarta: Pusat Studi Pariwisata, Universitas Gadjah Mada, 82-91.

Humaedi MA (2011) Mematahkan pewarisan kemiskinan. Jurnal Masyarakat dan Budaya, 13: 83110.

Ismail Z (2003) Dampak Kerusakan Lingkungan Pesisir terhadap Tingkat Sosial Ekonomi Masyarakat Nelayan. Jakarta: P2E-LIPI.

Kartodiharjo H \& Jhamtani H (2006) Politik Lingkungan dan Kekuasaan di Indonesia. Jakarta: Equinox Publishing Indonesia.

Kusnadi (1998) Jaringan Sosial sebagai Strategi Adaptasi Masyarakat Nelayan: Studi Kasus di Desa Pesisir, Kecamatan Besuki, Kabupaten Situbondo, Jawa Timur. Tesis, Program Studi Antropologi, Program Pascasarjana, Universitas Indonesia, Jakarta.

Kusnadi (2006) Konflik Sosial Nelayan: Kemiskinan dan Perebutan Sumberdaya Perikanan. Yogyakarta: LKiS.

Kusnadi (2016) Membangun Desa Pesisir Membangun Negara Maritim Indonesia. In: AAbdulrakhim. Menuju Kedaulatan Maritim Indonesia. Yogyakarta: Graha Ilmu, 41-56.

Kusnadi \& Sumarijono (2016) Paradoks Revolusi Biru: Perspektif Teori Involusi Clifford Geertz. Jember: Laporan Penelitian Fundamental DP2M, Universitas Jember.

Little D (1991) Varieties of Social Explanation: An Introduction to the Philosophy of Social Science. Oxford: Westview Press.

Mubyarto, Soetrisno L, \& Dove M (1984) Nelayan dan Kemiskinan: Studi Ekonomi Antropologi di Dua Desa Pantai. Jakarta: Rajawali Pers.

Muhammad Y (2016) Nasib Nelayan di Hari Nelayan Nasional. [Accessed 2 March 2018]. http:// beritagar.id/artikel/berita/nasibnelayan.

Muqtafa MK \& Nadila SM (2011) Climate change dan dampaknya terhadap komunitas nelayan dan masyarakat hutan. Jurnal Masyarakat dan Budaya, 13:151-167.

Perry RI (2010) Potential impacts of climate change on marine wild capture fisheries: An update. Journal of Agricultural Science, 149:1-13.

Rogelja N (2002) The ethnography of local tourism: Connections between fishery and tourism in Izola. Journal of Maritime Anthropological Studies, 1 (1):85-102. 
Suyanto B (1993) Dampak Motorisasi dan Komersialisasi Perikanan terhadap Perubahan Tingkat Pendapatan, Pola Bagi Hasil, dan Munculnya Polarisasi Sosial Ekonomi di Kalangan Nelayan Tradisional dan Nelayan Modern. Jakarta: Laporan Penelitian untuk YIIS.

Suyanto B (2011) Mekanisme survival, identifikasi kebutuhan, dan pemberdayaan nelayan miskin dalam masa krisis akibat kenaikan harga BBM. Jurnal Masyarakat, Kebudayaan, dan Politik, 24 (1):74-83.

Tingsabadh C (2005) Pengembangan Pariwisata dan Pengurangan Kemiskinan di Thailand. In: J Damanik, HA Kusworo, \& DT Raharjana (eds). Penanggulangan Kemiskinan Melalui Pariwisata. Yogyakarta: Pusat Studi Pariwisata, Universitas Gadjah Mada, 61-81.

Tuwo A (2011) Pengelolaan Ekowisata Pesisir dan Laut: Pendekatan Sosial-ekonomi, Kelembagaan, dan Sarana Wilayah. Sidoarjo: Brilian Internasional.

Yunus HS (2008) Dinamika Wilayah Peri-Urban: Determinan Masa Depan Kota. Yogyakarta: Pustaka Pelajar.

Widodo S (2012) Nelayan dan Kemiskinan. Bangkalan: Universitas Trunojoyo Press. 